\title{
EFEKTIFITAS TERAPI MUSIK KLASIK MONZAT DALAM MENINGKATKAN KECERDASAN EMOSI PADA ANAK SEKOLAH USIA DASAR
}

\author{
Alvi Rantna Yuliana ${ }^{1}$, Sri Endang Pujiastuti ${ }^{2}$, Elis Hartati ${ }^{3}$ \\ ${ }^{1,2,3}$ Fakultas Keperawatan Universitas Diponegoro \\ alviratna1607@gmail.com,rarastuti@yahoo.com, elis hartati@gmail.com
}

\begin{abstract}
ABSTRAK
Musik klasik monzart, dapat menyeimbangkan fungsi otak kanan dan otak kiri sehingga dapat digunakan untuk terapi meningkatkan kecerdasan emosi pada anak. Penelitian ini bertujuan melihat efektifitas Pemberian Terapi Musik Klasik monzart dalam Meningkatkan Kecerdasan Emosi pada Anak Usia sekolah Dasar.penelitian ini menggunakan jenis penelitian quasi eksperimental design tipe non equivalent control group design. Teknik pengumpulan data dengan menggunakan observasi dan kuisioner. Analisis data yang digunakan pada penelitian ini adalah analisis deskriptif dan analisis bivariat menggunakan uji Wilcoxon signed ranks test dan Mann-Whitney $U$ test.Hasil penelitian didapatkan bahwa 1) hasil skor total kecerdasan emosi perlakuan pada kelas kontrol dan pada kelas intervensi didapatkan bahwa harga sig adalah 0,001 atau $<0,05$, maka Ho ditolak dan Hi diterima. Artinya ada perbedaan yang signifikan antara skor nilai total kecerdasan emosi pada kelas kontrol dan pada kelas intervensi dengan perlakuan pemberian terapi musik klasik, 2) Berdasarkan hasil uji data analisis didapatkan hasil bahwa nilai $p$-value kelompok instrument melebihi $\alpha=0,05$. Sehingga dapat diambil kesimpulan bahwa terdapat pengaruh terapi masik klasik yakni Mozart terhadap kecerdasan emosional anak usia sekolah. Dalam hal ini nilai $p$-value $=0,001$ kelompok instrument lebih besar dari $\alpha=0,05,3$ )
\end{abstract}

Kata Kunci: Efektivitas Pemberian Musik Klasik, Kecerdasan Emosional, Anak SD

\begin{abstract}
classical music monzart, can balance right brain function and left brain so that it can be used for therapy to improve emotional intelligence in children. This research intent to determine effectiveness of monzart classical music in enhancing emotional intelligence on children. Research method that is utilized is my method experiment attention by quasi eksperimental design tipe non equivalent control group design. the data collection techniques being used consist of observations, interviews.

The data were analyzed using the Wilcoxon signed ranks test, and the Mann-Whitney $U$ test. The results showed an increase The results showed that 1) the total score of treatment emotional intelligence in the control class and in the intervention class found that the value of sig was 0.001 or $<0.05$, then Ho was rejected and Hi was accepted 2) Based on the results of the analysis data test, the results show that the p-value of the instrument group exceeds $\alpha=0.05$. So it can be concluded that there is an influence of classical mass therapy namely Mozart on the emotional intelligence of school-age children. In this case the $p$-value $=0.001$ instrument group is greater than $\alpha=0.05,3$ )
\end{abstract}

Keywords: Emotion Intelligence, Classical Music, Adolescent 


\section{PENDAHULUAN}

Kecerdasan emosional merupakan suatu kemampuan untuk mengenali perasaan diri sendiri dan perasaan orang lain, kemampuan memotivasi diri serta kemampuan untuk mengelola emosi dengan baik pada diri sendiri juga dalam berhubungan dengan orang lain (Indriani,2008). Kecerdasan emosi mencakup kemampuan-kemampuan yang berbeda, tetapi saling melengkapi, dengan demikian pola asuh yang diterapkan pada anak harus mencakup hal-hal yang mendukung terciptanya peningkatan kecerdasan emosi pada anak, pemberian pola asuh yang baik akan sangat mempengaruhi perkembangan kecerdasan emosi pada anak dan perkembangan sosial anak.(Yusuf,2007)

Kecerdasan Emosi atau EQ (Emosional Quotient), sebagai potensi kecerdasan vital manusia setelah IQ (Intellectual quotient), yang merupakan pengembangan kecerdasan manusia itu tidak bisa dilakukan secara partial dengan berat sebelah yaitu hanya dikonsentrasikan pada IQ semata, melainkan harus diimbangi dengan pengembangan emosi. Emosi merupakan reaksi yang kompleks yang mengandung aktifitas derajat yang tinggi dan adanya perubahan dalam kejasmanian serta berkaitan dengan perasaan yang kuat (walgito,2014). Dengan alhasil manusia tidak hanya pandai dalam mengoperasikan segi intelektualnya saja tapi juga cerdas di dalam mengelola emosinya (Golemman,2007). Di mana konon kisah tragis yang dialami setiap individu dalam masyarakat selalu diketahui berkaitan dengan ketidakmampuan individu masyarakat tersebut dalam menghadapi problem yang berkaitan dengan emosi, khususnya saat mereka dihadapkan dalam situasi yang mengharuskan mereka membuat keputusan penting dalam hidupnya. (endah,2008). Sehingga dengan begitu manusia yang rentan dengan emosi akan menjadi lebih besar dalam memperoleh kebahagian.

Kecerdasan emosional ini sungguh dibutuhkan setiap manusia dalam kehidupannya karena dapat dipastikan bahwa seorang individu tidak bisa lepas dari emosi diri dan dihadapkan dengan emosi orang lain, yang apabila dikelola dengan tepat maka berakibat baik bagi diri sendiri dan bagi orang lain. Misalnya, seorang anak SD yang berselisih pendapat dengan anak yang lain, disini dapat dilihat apakah anak SD dapat menerima pendapat atau tetap berikeras pada pendapatnya tanpa mempedulikan pendapat siswa lain.Tahap perkembangan kognitif menurut teori Peuget terbagi menjadi empat tahap yang berdasarkan umur, tahap-tahap perkembangan tersebut adalah tahap sensorimotor atau deria motor (dari lahir hingga 2 tahun), tahap praoperasi (2 hingga 7 tahun), tahap operasi konkrit (7 hingga 12 tahun), tahap operasi formal (12 tahun hingga dewasa). (Whaley \& Wong, 2009). Berdasarkan tahap perkembangan kognitif di atas dapat dijelaskan bahwa untuk anak kelas 5 SD, masuk pada tahap ketiga yaitu operasi konkrit. Operasi konkrit merupakan tahap perkembangan kognitif pada anak yang memiliki usia 7 hingga 12 tahun. Pada tahap ini, anak-anak tidak lagi berfikir secara egosentrik sehingga perasaan ingin tahu menjadikan anak-anak pada tahap ini akan gemar menanyakan sesuatu yang menarik minat mereka kepada orang yang lebih dewasa. Anak-anak akan mulai belajar bermain dan bergaul dengan rekan-rekan yang sebaya karena pada tahap ini mereka akan mulai memasuki zaman persekolahan.

Anak Sekolah Dasar ( SD) merupkan tahap pertama dalam pendikdikan formal dimana terjadi proses tumbuh kembang di mana di mulai kedisiplinan,atitude dalam tingkah laku, empati dan menghargai terhadap orang 
lain serta belajar bertangung jawab. pada masa ini anak berada dalam masa pencarian identitas diri, serta melemahnya ikatan afektif dengan orangtua. Anak SD juga mulai memperluas hubungan dengan teman sebaya yang pada umumnya menjadi anggota kelompok sebaya (peer group). Dalam kelompok, anak menjadi sangat bergantung dan terikat, hal ini terlihat dengan terjadinya konformitas kelompok yang membuat remaja berusaha untuk dapat menyesuaikan diri dan menyatu dengan kelompoknya.

Menurut Mozart belakangan ini ditemukannya musik sebagai media pembangunan kecerdasan emosional, yang menjadi temuan baru yang menarik, sehingga mampu membawa masa depan manusia kearah yang lebih baik. Musik sangat mempengaruhi perkembanngan IQ (Intelegent Quotient) dan EQ (Emotional Quotient). Seorang anak yang sejak kecil terbiasa mendengarkan musik akan lebih berkembang kecerdasan emosional dan intelegensinya dibandingkan dengan anak yang jarang mendengarkan musik ${ }^{6}$. IQ menyumbang paling banyak $20 \%$ bagi kesuksesan hidup seseorang, sedangkan $80 \%$ ditentukan oleh Emotional Quotient (EQ). Kecerdasan akademis praktis tidak menawarkan persiapan untuk menghadapi gejolak yang ditimbulkan oleh kesulitan hidup. Banyak bukti yang memperlihatkan bahwa orang yang secara emosional cakap mengetahui dan menangani perasaan mereka sendiri dengan baik, serta mampu membaca dan menghadapi perasaan orang lain dengan efektif, memiliki keuntungan dalam setiap bidang kehidupan (Anonymous,2014).

Musik merupakan seni yang melukiskan pemikiran dan perasaan manusia lewat keindahan suara. Sebagaimana manusia menggunakan kata-kata untuk mentransfer suatu konsep, ia juga menggunakan komposisi suara untuk mengungkapkan perasaan batinnya. Seperti halnya ragam seni lain, musik merupakan refleksi perasaan suatu individu atau masyarakat. Musik merupakan hasil dari cipta dan rasa manusia atas kehidupan dan dunianya. Musik yang dapat dipergunakan untuk pendidikan dan alat mempertajam kecerdasan manusia adalah musik yang mempunyai keseimbangan 3 unsur: Melody, Ritme, dan Timbre (tone colour). Musik harus dikenalkan sedini mungkin pada anak bahkan sejak dalam kandungan anak sudah dirangsang dengan jenis musik yang dapat mengembangkan kecerdasan anak yaitu jenis musik klasik. Memperdengarkan musik atau suara lain yang menyenangkan bagi bayi yang masih dalam kandungan ternyata bisa menstimulasi sistem pendengaran mereka dan berpengaruh positif pada respons mereka terhadap musik dan suara-suara lain setelah mereka lahir. Bayi-bayi ketika di dalam kandungan mendengarkan musik yang rileks dan menenangkan ternyata tumbuh dan bertambah berat badannya dengan mudah serta lebih damai dengan diri mereka sendiri dan lingkungan sekitarnya, begitu mereka hadir di "dunia nyata" (orizt,2012). Seorang anak yang sejak kecil terbiasa mendengarkan musik akan lebih berkembang kecerdasan emosionalnya dibandingkan dengan anak yang jarang mendengarkan musik. Musik yang didengar berupa irama dan nada-nada yang teratur dari perpaduan seimbang antara beat, ritme dan harmoni (Sujiono,2009)

Otak manusia terdapat reseptor (sinyal penerima) yang bisa mengenali musik. Otak bayi pun sudah dapat menerima musik tersebut meski dengan kemampuan terbatas karena pertumbuhan otaknya belum sempurna. Musik merupakan salah satu stimulasi untuk mempercepat dan mempersubur perkembangan otak bayi. Bila anak terbiasa mendengar musik yang indah, banyak 
sekali manfaat yang akan dirasakan oleh anak. Tidak saja meningkatkan kognisi anak secara optimal, juga membangun kecerdasan emosional. Selain manfaat kognitif dan emosi, masih banyak lagi kegunaan musik bagi anak-anak. Contohnya, meningkatkan perkembangan motoriknya, meningkatkan kemampuan berbahasa, matematika, sekaligus kemampuan sosialnya, dan membangun rasa percaya diri.Musik juga bisa menjadi kekuatan positif bagi kesehatan mental, menenangkan, santai dan menjadi stimulan bagi pengembangan intelektual dan kognitif. Hal ini berlaku untuk orang dewasa, remaja, dan anak-anak. Musik dapat mempengaruhi emosi kita, musik dapat membuat "saluran" dalam pikiran kita, pola berpikir. Musik dapat menyampaikan gagasan dan ideologi, secara kuat dan emosional menyampaikan cara hidup. Anak-anak, remaja dan bahkan bayi secara potensial mendapatkan manfaat dari mendengarkan musik, karena musik bisa menjadi stimulan untuk pengembangan intelektual dan kognitif. Musik dapat memiliki pengaruh yang menenangkan. Susunan genetik kita memiliki bantalan dalam cara otak memproses musik. Bagi sebagian yang lain kita menyerap setiap catatan, setiap emosi, dan itu menjadi bagian dalam dari profil psikologi kita. Sejak anak muda, dan sekarang, anak-anak, sering mendengarkan musik berjamjam setiap hari dari berbagai sumber, hal ini membantu menjelaskan dampak bahwa musik mungkin memiliki andil dalam hal kesehatan mental anak-anak dan gangguan mood remaja. Musik juga menemukan bahwa musik dapat, memperbaiki kepercayaan diri, mengembangkan ketrampilan sosial, menaikkan perkembangan motorik persepsi dan perkembangan psikomotor (Astuti,2007)

Berdasarkan survei yang telah dilakukan, ternyata ditemukan hasil bahwa generasi sekarang lebih banyak mengalami kesulitan emosi dan sosial daripada generasi sebelumnya, generasi sekarang cenderung lebih kesepian, pemurung, mudah cemas, gugup, impulsif, dan agresif. (Safaria,2009) Keadaaan tersebut hendaknya mendapatkan perhatian khusus. Anak sebagai generasi penerus perlu dibekali kemampuan untuk mengoptimalkan seluruh potensi yang dimiliki dan meminimalkan kelemahan-kelemahan yang ada.

Intervensi musik berpengaruh signifikan meningkatkan kecerdasan emosional orang dewasa muda (Vijayabanu et all,2016). Musik dan pendidikan kognitif dapat memiliki pengaruh positif terhadap fungsi anak. Penelitian lain didapatkan bahwa Ada pengaruh terapi musik klasik terhadap kecerdasan emosi pada anak autis. pengaruh yang signifikan pada uji eksperimen musik kasik terhadap kecerdasan emosional anak.

Berdasarkan studi pendahulan yang di lakukan dengan wawancara terhadap kepala sekolah yang dilakukan di SD N 1 Ngetuk Gunung Wungkal Kabupaten Pati ditemukan fenomena-fenomena seperti: Anak cepat bosan saat mendengarkan pelajaran, tidak fokus dalam mengikuti pembelajaran yang diberikan guru dan banyak main geget dirumah,game online, ada anak yang selalu terlihat pemurung,anak yang mudah sekali marah dan mebuli teman ada anak yang mudah sekali menangis,tersingung.serta banyak anak yang cenderung tidak mau berbagi dan bekerja sama dengan teman sekelasnya, ini sering terjadi saat anak mulai memasuki kelas empat menuju lima

Berdasarkan penjelasan latar belakang di atas maka peneliti tertarik melakukan penelitian tentang Efektifitas Pemberian Terapi Musik Klasik Dalam Meningkatkan Kecerdasan Emosi pada Agregat Anak Usia Dasar. 


\section{METODE PENELITIAN}

kuantitatif quasi eksperimental dengan desain non equivalent control group design. Penelitian ekspeimen dilakukan bertujuan untuk mengetahui suatu gejala atau pengaruh yang timbul, sebagai suatu akibat dari adanya perlakuan atau intervensi tertentu. Penelitian quasi eksperimental design tipe non equivalent control group design terdapat kelompok kontrol (tidak diberi perlakuan) dan kelompok eksperimen (diberi perlakuan) yang diambil tidak secara random, karena populasinya berupa kelas. Pada penelitian ini menggunakan dua kelas yang dijadikan dua kelompok yaitu 1 kelas kelompok control dan 1 kelas kelompok eksperimen. Kedua kelompok dilakukan pretest untuk mengetahui keadaan awal siswa sebelum diberi pelakuan atau treatment.Data dianalisis secara univariat dan bivariat menggunakan uji Wilcoxon signed ranks test dan Mann-Whitney $U$ test

\section{HASIL DAN PEMBAHASAN}

\section{Hasil}

Tabel 1. Analisis Bivariat Kecerdasan Emosional Siswa Sebelum dan Sesudah Dilakukan Permainan Terapi Musik Klasik Pada Kelompok Kontrol dan Intervensi $(\mathrm{N}=40)$

\begin{tabular}{|c|c|c|c|c|c|c|}
\hline \multirow[b]{2}{*}{ Kelompok } & \multirow[b]{2}{*}{ Variabel dan Dimensi } & \multicolumn{2}{|c|}{ Pre Test } & \multicolumn{2}{|c|}{ Post Test } & \multirow[b]{2}{*}{$\begin{array}{c}p- \\
\text { value }\end{array}$} \\
\hline & & Pre Test & $\begin{array}{l}\text { Min- } \\
\text { max }\end{array}$ & Post test & $\begin{array}{l}\text { Min- } \\
\text { max }\end{array}$ & \\
\hline \multirow[t]{6}{*}{ Kontrol } & $\begin{array}{l}\text { Kecerdasan } \\
\text { Emosional }\end{array}$ & $44,75 \pm 4,49$ & (34-53) & $45,15 \pm 5,53$ & $(35-57)$ & $\mathbf{0 , 0 5 7}$ \\
\hline & Kesadaran Emosi & $8,75 \pm 1,33$ & $(7-12)$ & $8,90 \pm 1,45$ & $(7-12)$ & 0,068 \\
\hline & Pengendalian Emosi & $8,70 \pm 0,98$ & $(7-11)$ & $8,95 \pm 1,11$ & $(7-11)$ & 0,051 \\
\hline & Memotivasi Diri & $9,15 \pm 1,42$ & $(6-11)$ & $9,25 \pm 1,05$ & $(7-11)$ & 0,063 \\
\hline & $\begin{array}{l}\text { Membina Hubungan } \\
\text { Sosial }\end{array}$ & $9,05 \pm 0,86$ & $(7-10)$ & $9,45 \pm 1,00$ & $(7-11)$ & 0,053 \\
\hline & Empati & $9,10 \pm 1,33$ & $(7-12)$ & $9,20 \pm 1,32$ & $(7-12)$ & 0,084 \\
\hline \multirow[t]{6}{*}{ Intervensi } & $\begin{array}{l}\text { Kecerdasan } \\
\text { Emosional }\end{array}$ & $\begin{array}{l}45,60 \\
\pm 5,06\end{array}$ & $(33-56)$ & $47,35 \pm 5,77$ & $(33-56)$ & $\mathbf{0 , 0 0 1}$ \\
\hline & Kesadaran Emosi & $8,65 \pm 1,23$ & $(6-10)$ & $8,95 \pm 1,39$ & $(7-11)$ & 0,048 \\
\hline & Pengendalian Emosi & $9,25 \pm 1,12$ & $(7-11)$ & $9,65 \pm 1,18$ & $(7-11)$ & 0,023 \\
\hline & Memotivasi Diri & $9,50 \pm 1,54$ & $(7-12)$ & $9,75 \pm 1,25$ & $(7-12)$ & 0,102 \\
\hline & $\begin{array}{l}\text { Membina Hubungan } \\
\text { Sosial }\end{array}$ & $9,30 \pm 1,30$ & $(7-12)$ & $9,75 \pm 1,25$ & $(7-12)$ & 0,024 \\
\hline & Empati & $8,90 \pm 1,92$ & $(6-12)$ & $9,25 \pm 1,86$ & $(6-12)$ & 0,020 \\
\hline
\end{tabular}

Berdasarkan Tabel 1 hasil analisis menggunakan uji Wilcoxon dapat disimpulkan bahwa pada kelompok kontrol tidak terdapat perbedaan kecerdasan emosional dan ke-lima dimensinya (kesadaran emosi, pengendalian emosi, memotivasi diri, membina hubungan sosial, dan empati) secara signifikan antara pre-test dan post-test ( $p$-value $>\alpha=0,05$ ). Sedangkan pada kelompok intervensi terdapat perbedaan signifikan kecerdasan emosional dan ke-empat dimensinya (kesadaran emosi, pengendalian emosi, membina hubungan sosial, dan empati) antara pre-test dan post-test $(p$-value $<\alpha=0,05)$. Hanya satu dimensi pada kelompok intervensi yaitu memotivasi diri berdasarkan analisis statistik tidak terdapat perbedaan secara signifikan antara pre-test dan post-test ( $p$ value $=0,102>\alpha=0,05$ ) 


\section{Perbedaan Kecerdasan Emosional Siswa Pada Kelompok Eksperimen dan Kontrol Sebelum dan Seetelah dilakukan Terapi Musik Klasik}

Tabel 2. Uji Normalitas dengan Shapiro-Wilk

\begin{tabular}{lccc}
\hline \multicolumn{1}{c}{ Variabel } & Statistic & df & p-value \\
\hline Pretest Kecerdasan Emosional & 0,974 & 40 & 0,489 \\
Posttest Kecerdasan Emosional & 0,968 & 40 & 0,312 \\
Peningkatan (Selisih Pretest-Posttest) & 0,890 & 40 & 0,001 \\
\hline
\end{tabular}

Berdasarkan Tabel 2 dengan menggunakan Shapiro-Wilk bahwa data pretest dan posttest kecerdasan emosional berdistribusi normal ( $p$-value $>0,05)$. Sedangkan data selisih pretest dan posttest tidak berdistribusi nromal ( $p$-value < 0,05 ). Sehingga uji data tidak berpasangan yang digunakan jika data berdistribusi normal yaitu pada data pretest dan posttest kecerdasn emosional adalah uji independent sample $t$ test dan uji data tidak berpasangan yang digunakan jika data berdistribusi tidak normal yaitu data selisih pretest dan posttest pada kelompok kontrol dan eksperimen adalah uji Mann-Whitney.

Tabel 3. Analisis Bivariat Kecerdasan Emosional Siswa Sebelum dan Sesudah Dilakukan Permainan Terapi Musik Klasik Pada Kelompok Kontrol dan Eksperimen $(\mathrm{N}=40)$

\begin{tabular}{|c|c|c|c|c|c|c|}
\hline \multirow{2}{*}{ Variabel } & \multirow{2}{*}{$\begin{array}{c}\text { Mean } \\
\text { difference }\end{array}$} & \multicolumn{2}{|c|}{ Kontrol } & \multicolumn{2}{|c|}{ Eksperimen } & \multirow{2}{*}{$p$-value } \\
\hline & & Mean & SD & Mean & SD & \\
\hline $\begin{array}{l}\text { Pretest Kecerdasan } \\
\text { Emosional }\end{array}$ & 0,85 & 44,75 & 4,49 & 45,60 & 5,06 & $0,578^{*}$ \\
\hline $\begin{array}{l}\text { Posttest } \\
\text { Kecerdasan }\end{array}$ & 2,20 & 45,15 & 5,53 & 47,35 & 5,77 & $0,047 *$ \\
\hline $\begin{array}{l}\text { Emosional } \\
\text { Selisih }\end{array}$ & 2,00 & 1,85 & 1,38 & 2,85 & 1,33 & $0,033^{* *}$ \\
\hline
\end{tabular}

Berdasarkan Tabel 3 hasil analisis menggunakan uji independent sample t test dapat disimpulkan bahwa tidak terdapat perbedaan kelompok kontrol dan eksperimen sebelum diberikan terapi musik klasik ( $\mathrm{p}$-value $=0,578>0,05$ ) Dengan menggunakan uji yang sama dapat disimpulkan bahwa terdapat perbedaan kelompok kontrol dan eksperimen setelah diberikan terapi musik klasik ( $\mathrm{p}$-value $=$ $0,047<0,05)$. Sedangkan dengan menggunakan uji Mann Whitney bahwa terdapat perbedaan selisih pada kelompok kontrol dan eksperimen ( $\mathrm{p}$-value $=$ $0,033<0,05)$

\section{Pembahasan}

\section{Efektifitas Pemberian Terapi Musik Klasik Dalam Meningkatkan Kecerdasan Emosi pada Agregat Anak Usia Dasar}

Berdasarkan analisis data di dapatkan bahwa hasil skor total kecerdasan emosi perlakuan pada kelas kontrol dan pada kelas intervensi didapatkan bahwa harga sig adalah 0,001 atau < 0,05, maka Ho ditolak dan Hi diterima. Artinya ada perbedaan yang signifikan antara skor nilai total kecerdasan emosi pada kelas kontrol dan pada kelas intervensi dengan perlakuan pemberian terapi musik klasik. 
Berdasarkan hasil uji data analisis didapatkan hasil bahwa nilai p-value kelompok instrument melebihi $\alpha=0,05$. Sehingga dapat diambil kesimpulan bahwa terdapat pengaruh terapi masik klasik yakni Mozart (Capable) terhadap kecerdasan emosional anak usia sekolah. Dalam hal ini nilai $p$-value $=0,001$ kelompok instrument lebih besar dari $\alpha=0,05$.

Mendengarkan musik dapat menimbulkan emosi yang dalam istilah terapi, aktifitas ini dikatakan sebagai aktifitas berbagai kognisi dan perasaan. Dilihat dari aspek kognitif dan aktifitas otak bisa dikatakan bahwa setiap orang yang sehat dapat bereaksi terhadap musik baik secara fisik maupun psikis. Selain itu juga dengan menggunakan musik klasik sebagai media atau instrument dalam mengembangkan kecerdasan emosional anak usia dini karena musik klasik adalah salah satu media yang cukup relevan bila diaplikasikan dalam pengembangan kecerdasan emosional anak. Sehingga anak lebih mengelola emosi yang dirasakannya karena musik klasik tersebut terdapat komponen-komponen atau moleku-molekul yang dapat melepaskan ketegangan-ketegangan sehingga memberikan rasa nyaman dan tenang.

Musik klasik (efek mozart) memang memberikan pengaruh positif bagi subyek pada kelompok eksperimen selama pemberian perlakuan maupun setelah mereka menerapkan secara individu. Musik klasik (efek mozart) mempunyai manfaat dan fungsi terhadap kejenuhan (burnout) belajar, antara lain musik sebagai hiburan atau relaksasi (mendamaikan hati, memberikan rasa santai dan nyaman), terapi kesehatan (mereduksi kelelahan fisik, denyut jantung), peningkatan kecerdasan (keterkaitan dengan peningkatan kognitif seseorang), ekspresi emosional (mengontrol perasaan emosi), gambaran kepribadian (dapat meningkatkan motivasi sesorang ketika merasa lelah), dan peningkatan konsentrasi dimana manfaat diatas berkaitan dengan kejenuhan dan indikator pembentuk kejenuhan (burnout) belajar.

Musik klasik karya Mozart memiliki tempo yang lambat, seperti yang disampaikan oleh Jenskins (Abdillah dan Saleh, 2010) Sonata for Two Pianos in D Major merupakan salah satu karya Mozart yang mempunyai karakter yang lambat. Djohan (Winja Susanti dan Ainur Rohmah, 2011) berpendapat bahwa musik dengan tempo lambat memiliki dampak positif. Seseorang yang berada pada kondisi seimbang akan lebih mudah dalam mengakses pikiran dan pemahaman. Kondisi seimbang tersebut terjadi ketika semua fungsi fisik seseorang sedang melambat. Musik dengan tempo ini mampu memperlambat detak jantung yang bergerak cepat sehingga hal tersebut juga dapat dirasakan oleh siswa.

Satiadarma dan Campbell (Primadita, 2012) menjelaskan bahwa intervensi dengan musik klasik berdampak secara fisik dapat mempengaruhi aktivitas sistem saraf otonom tubuh, munculnya beberapa respon yang bersifat spontan dan tidak terkontrol, misalnya mengetukkan jari. Musik klasik juga dapat mempengaruhi pernafasan, denyut jantung, denyut nadi, tekanan darah, mengurangi ketegangan otot dan memperbaiki gerak dan kordinasi tubuh, meningkatkan produktivitas suhu tubuh, serta mengatur hormon-hormon yang berkaitan dengan stres.

Musik juga mempengaruhi terhadap kognitif, Jenskins (Abdillah dan Saleh, 2010) musik klasik dengan tempo lambat dapat meningkatkan gelombang otak alpha sehingga mampu membuat seseorang menjadi rileks. Musik klasik akan membawa otak pada gelombang alpha. Gelombang itu akan menstimulus serabut- 
serabut neuron korteks hingga bekerja maksimal. Selain itu gelombang ini mampu membuat seseorang menjadi rileks sehingga akan lebih mudah dalam menerima informasi. Musik Mozart berpengaruh dapat memperlambat dan menyeimbangkan otak selain itu musik mozart yang lembut dan seimbang antara beat, ritme serta harmoninya dapat memodifikasi gelombang otak. Proses musik yang didengar akan menggetarkan saraf yang ada didalam kepala untuk memicu emosi. Gelombang beta di otak dengan sinyal 14-20 gelombang per detik akan diubah menjadi gelombang alpha atau sekitar 8-13 gelombang per detik, gelombang ini membuat seseorang menjadi rileks.

Hal senada juga disampaikan oleh Djohan yang menyebutkan bahwa musik dapat membuat seseorang dari kondisi beta (terjaga) menjadi ke kondisi alfa (mediatif), sedangkan yang bersangkutan tetap sadar dan terjaga. Musik yang didengar akan menggetarkan saraf yang ada di dalam otak dan memicu emosi serta sensasi fisik, seperti rasa tenang, takut, gembira atau sedih

Secara emosi, Paget (Winja Susanti dan Ainur Rohmah, 2011) menyatakan bahwa efek musik yang dapat terasa pada tubuh dan pikiran manusia adalah pemunculan karakter dan emosi seseorang, ditandai dengan berpengaruh pada detak jantung, metabolisme, penurunan level stres, berkurangnya kelelahan, serta kreativitas seseorang.

Hasil penelitian mengenai pengaruh musik klasik terhadap kecerdasan emosional anak pernah diteliti. Hasil penelitian yang dilakukan sejalan dengan penelitian yang dilakukan oleh :

Penelitian yang dilakukan di TK Kemala Bhayangkari 06 Kalasan. Hasil penelitian pada taraf signifikansi $1 \%$ didapatkan bahwa terdapat pengaruh yang signifikan pada uji intervensi musik kasik terhadap kecerdasan emosional anak (t hitung > t tabel) yakni $2.931>2.88$. Selain itu juga didapatkan perbedaan pada kelas kontrol dengan didapatkan t hitung kontrol sebesar $0.316(0.316>2.26)$. Jadi jika dilihat dari taraf signifikansi 1\%, kelompok kontrol tidak terjadi perubahan sebelum dan sesudah treatmen. Sedangkan untuk kelompok intervensi terjadi perubahan yang signifikan sebelum dan sesudah treatment ( Ngalifah,2010)

Penelitian lain yang dilakukan SMA YP Unila Bandar Lampung tahun pelajaran 2017/2018. Hasil penelitian didapatkan bahwa terdapat adanya perbedaan kecerdasan emosional peserta didik setelah di laksanakan layanan kelompok menggunakan musik. Hasil perhitungan rata-rata skor kecerdasan emosional kelompok intervensi sebelum diberikan treatmen musik adalah 38.40 dan setelah mengikuti layanan konseling kelompok menggunakan musik meningkat menjadi 75,20. Sedangkan pada kelompok kontrol adalah 37,5 dan pada saat posttest mendapatkan peningkatan menjadi 61,7. Dari hasil uji-T dengan df $=18$ dengan taraf signifikan 0,05 sebesar 2,10093, dan diperoleh thitung $=$ 4,502. Selain itu juga didapatkan nilai thitung > t tabel, maka 14,727 > 2,10093, maka Ho ditolak dan Ha diterima disimpulkan bahwa pemberian musik dapat meningkatkan kecerdasan emosional peserta didik kelas XI di SMA YP Unila Bandar Lampung tahun pelajaran 2017/2018. Selain itu juga menujukkan bahwa rata-rata tingkat kecerdasan emosional peserta didik kelas XI SMA YP Unila Bandar Lampung setelah dilaksanakan layanan konseling kelompok dengan menggunakan musik menjadi lebih baik dan meningkat.

Vijayabanu dan Menon (2016) dengan judul Impact Of Music Intervention On Emotional Intelligence didapatkan bahwa pemberian intervensi musik dapat 
meningkatkan kecerdasan emosional orang dewasa muda dengan didapatkan nilai t hitung sebesar 2,24. Selain itu didapatkan bahwa nilai rata-rata skor tes Pra dan Pasca Inteligen Emosional yaitu 169,90 dan 221,60 dengan standar deviasi masing-masing 14,39 dan 71,62.

Penelitian yang dilakukan kepada Mahasiswa Jurusan Musik Institut Seni Indonesia Yogyakarta. Hasil penelitian didapatkan bahwa terdapat hubungan antara karakter musik klasik dan pop-jazz dengan EQ mahasiswa, dibuktikan dengan perbedaan yang signifikan antara nilai EQ pemain musik klasik dan nilai EQ pemain musik pop-jazz pada mahasiswa Jurusan Musik ISI Yogyakarta. Berdasarkan uji perbedaan didapatkan bahwa diperoleh skor t-test sebesar 2,987 dan nilai signifikansi $0,004<0,005$.

Penelitian yang dilakukan di TK Education 21 Kulim Pekanbaru. Hasil penelitian dodapatkan bahwa secara umum kecerdasan emosional sebelum diberikan perlakuan berada pada kategori kurang. Hal ini terlihat dari jumlah anak yang termasuk kategori baik tidak ada (0\%), kategori cukup (30\%) ada 6 anak, dan kategori kurang $(70 \%)$ ada 14 anak. Sedangkan setelah diberikan perlakuan dengan mendengarkan musik, kecerdasan emosional secara umum mengalami peningkatan menjadi kategori cukup. Ada 3 anak yang berada dikategori baik (15\%), 17 anak dengan kategori cukup (85\%), dan tidak ada lagi anak yang berada dikategori kurang $(0 \%)$. Selain itu juga berdasarkan analisis menggunakan uji " $t$ " diperoleh $\mathrm{t}$ hitung sebesar 10,94 dengan $\mathrm{dk} 38, \mathrm{t}$ tabel $5 \%=2,021$. Karena $\mathrm{t}$ hitung $(10,94)$ lebih besar dari t tabel $(2,021)$ maka Ha diterima artinya ada pengaruh mendengarkan musik terhadap kecerdasan emosional anak usia 4-5 tahun di TK Education 21 Kulim Pekanbaru ( Adyah et al,2013).

Penelitian yang dilakukan di TK Kartika IV-9 Surabaya. Hasil penelitian didapatkan bahwa hasil penelitian rata-rata tingkat kecerdasan emosioanal anak sebelum treatment 34,41 dan sesudah treatment 41,88, maka disimpulkan bahwa terjadi peningkatan kecerdasan emosi sebelum dan sesudah diberikan treatment. Hasil uji jenjang bertanda wilcoxon juga menunjukkan Thitung adalah 0 dan Ttabel adalah 23. Dimana Thitung $<$ Ttabel yaitu $0<23(\alpha=0,01)$, sehingga $\mathrm{H}_{0}$ ditolak dan Ha diterima dan dapat dinyatakan bahwa ada pengaruh signifikan musik terhadap kecerdasan emosional anak kelompok A di TK Kartika IV-9 Surabaya.

Penelitian yang dilakukan di Kelompok Bermain Kasih Ibu. Hasil penelitian didapatkan bahwa anak yang sering didengarkan music di kehidupannya seperti kebiasaan orang tua memutarkan musik di pagi hari dan juga kebiasaan orang tua dalam mengajak anak untuk bernyayi atau menirukan lagu-lagu yang didengarkannya dengan cara ini secara tidak langsung anak akan mengembangkan kecerdasan emosinya, memahami tentang emosinya sendiri (MED) anak dapat memahami emosi marah, senag atau sedih secara sempurna, mengelolah emosi (ME) pengendalian emosi dimana anak dapat mengontor emosi secara wajar dan tidak meluap-luap, dapat menjalin pertemanan dengan baik dengan lingkungannya (MHDOL). Penelitian ini menggunakan kualitatif (fitrroh dan khasanah 2016).

Sedangkan penelitian yang dilakukan tidak sejalan dengan penelitian yang dilakukan oleh Nikmanesh (2012) didapatkan bahwa tidak ada yang signifikan/perbedaan antara nilai rata-rata pada tingkat kecerdasan emosional untuk pria dan wanita setelah terapi musik dengan didapatkan nilai $\mathrm{t}$ hitung sebesar 0,652 dan nilai sig (p) sebesar 0,517>0,05. Dimensi/indikator kecerdasan 
emosional yang dipakai pada penelitian ini adalah dimensi intrapersonal, dimensi interpersonal, manajemen stres, kemampuan beradaptasi, kecerdasan emosional total dan kesan positif

\section{SIMPULAN DAN SARAN \\ Simpulan}

Berdasarkan analisis data di dapatkan bahwa hasil skor total kecerdasan emosi perlakuan pada kelas kontrol dan pada kelas eksperimen didapatkan bahwa harga sig adalah 0,001 atau <0,05, maka Ho ditolak dan Hi diterima. Artinya ada perbedaan yang signifikan antara skor nilai total kecerdasan emosi pada kelas kontrol dan pada kelas eksperimen dengan perlakuan pemberian terapi musik klasik

\section{Saran}

Berdasarkan hasil pembahasan, penulis memberikan saran-saran kepada beberapa pihak yaitu :

1. Diharapkan para perawat dapat mempertahankan kecerdasan emosi anak dan perilaku prososial serta meningkatkan kecerdasan emosi para anak yang masih dalam kategori sedang misalnya dengan menggunakan instrumen jenis musik yang lainnya sesuai dengan umur anak atau bahkan menggunakan instrumen lannya seperti memberikan workshop/pelatihan kepada anak untuk meningkatkan pengetahuan serta kemampuan pribadinya.

2. Siswa perlu menindak lanjuti dan meningkatkan kecerdasan emosional sehingga dapat mencapai tujuan agar mampu mengelola emosi dengan baik.

3. Untuk peneliti selanjutnya disarankan dapat menggunakan instrument musik lainnya seperti musik lain misal POP atau memakai jenis musik yang lebih netral sesuai usia yang akan diberikan intervensi

\section{DAFTAR PUSTAKA}

Abdillah dan Saleh. (2010). Pengaruh Musik Mozart terhadap Tingkat Kecemasan Pasien Dokter Gigi. Jurnal Kedokteran Gigi, Vol. 101, 22-28[

Anonymous, 2014. Mempersiapkan IQ dan EQ Anak, Percuma IQ Tinggi Jika

Tak Diimbangi EQ, (Online), (http://www.pikiran-rakyat.com, diakses 20 April 2017).

astuti, Idayu. 2007. Mengenal Autisme \& Terapinya. http://autisme.or.id. Diakses 20 April 2017

Indriyani, Widian Nur. 2008. Panduan Praktis Mendidik Anak Cerdas Intelektual dan Emosional. Yogyakarta : Logung Pustaka.

Baron, Reuven. (2007, April). Baron model of emotional-social intelligence. Januari $\quad 2010 . \quad$ http://www.reuvenbaron.org/baronmodel/essay.php?i=3\#intra

Behrman., Kliegman. \& Arvin. 2010. Ilmu Kesehatan Anak (Edisi: 15, Vol. 2). Jakarta : EGC

Christanday, Andreas. 2007. Pengaruh Musik pada Anak. http://angelfire.com. Diakses 20 April 2017

Goleman, D. 2007. Kecerdasan Emosional. Jakarta: Gramedia Pustaka Utama. 
Hogenes, Michel., Van Oers, Bert., Diekstra, René F.W. The impact of music on child functioning. The European Journal of Social \& Behavioural Sciences (eISSN: 2301-2218)

Jorfi., et al., 2010. Emotional Intelligence: The Relationship between Self-Regard and Communication Effectiveness. Journal World Academy of Science, Engineering and Technology International Journal of Social, Behavioral, Educational, Economic, Business and Industrial Engineering Vol:4, No:9, 2010

Michelangelo, Lori. 2014. The overall impact of emotional intelligence on nursing students and nursing. Journal Department of Nursing, National University, La Jolla, California, USA

Ngalifah, Siti. 2010. Pengaruh Musik Klasik Terhadap Kecerdasan Emosional Anak Di Tk Kemala Bhayangkari 06 Glondong Tirtomartani Kalasan Sleman Yogyakarta Tahun Ajaran 2009/2010. Skripsi Jurusan Kependidikan Islam Fakultas Tarbiyah Universitas Islam Negeri Sunan Kalijaga Yogyakarta

Ortiz, Jhon. 2012. Menumbuhkan Anak-anak Yang Bahagia, Cerdas dan Percaya Diri Dengan Musik. Jakarta : Gramedia Pustaka Utama

Primadita, Adhe. 2012. Efektivitas Intervensi Terapi Musik Klasik Terhadap Stress dalam Menyusun Skripsi Pada Mahasiswa PSIK UNDIP Semarang. Jurnal PSIK FK UNDIP Semarang

safaria, T. (2009). Manajemen Emosi Sebuah Panduan Cerdas Bagaimana Mengelola Emosi Positif Dalam Hidup Anda. Yogyakarta : Bumi Aksara

Sujiono, Bambang dan Nurani Yuliani. 2009. Mencerdaskan Perilaku Anak Usia Dini. Jakarta : Gramedia

Susilowati, Wiwik., Peristyowati, Yuly., Kusumawati, Prima Dewi. 2012. Pengaruh Terapi Musik Klasik Terhadap Kecerdasan Emosi Pada Anak Jurnal keperawatan 2

Supartini. 2007. Buku Ajar Konsep Dasar Keperawatan Anak. Jakarta. EGC

Yusuf, Syamsu. 2007. Psikologi Perkembangan Anak dan Remaja. Bandung: PT Remaja Rosdakarya

Winja Susanti, Devi., Ainur Rohmah, Faridah. (2011). Efektivitas Musik Klasik dalam Menurunkan Kecemaan Matematika (Math Anxiety) Pada Siswa Kelas XI. Jurnal Humanitas, Vol. 8 (2).

Wong, D.L., Hockenberry, M, Eaton, Wilson, D., Winkelstein, M, L., \& Schwartz, P. 2009. Buku ajar keperawatan pediatrik. Vol.1. Jakarta : EGC 